Original Research Paper

\title{
Pemberdayaan Masyarakat Melalui Pelatihan Teknis Beternak Kambing di Desa Gunungsari Kabupaten Lombok Barat
}

\author{
M. Yamin ${ }^{1 *}$, Khairuddin ${ }^{1}$, Putu Artayasa ${ }^{1}$, Khairunnisyah Sahidu $^{2}$ Darmansyah $^{3}$ \\ 1. Program Studi Pendidikan Biologi PMIPA FKIP Universitas Mataram \\ 2. Program Studi Pendidikan Fisika PMIPA FKIP Universitas Mataram \\ 3. Program Studi Ilmu Pemerintahan, FISIPOL Universitas Muhamadiyah Mataram
}

https://doi.org/10.29303/jpmpi.v3i2.990

Sitasi: Yamin, M., Khairuddin., Artayasa, P., Sahidu, K \& Darmansyah. (2021). Pemberdayaan Masyarakat Melalui Pelatihan Teknis Beternak Kambing di Desa Gunungsari Kabupaten Lombok Barat. Jurnal Pengabdian Magister Pendidikan IPA, 4(3)

\section{Article history}

Received: 5 September 2021

Revised: 23 September 2021

Accepted: 24 September 2021

*Corresponding Author: M.

Yamin, Program Studi

Pendidikan Biologi, PMIPA, FKIP, Universitas Mataram, Mataram, Indonesia

Email:

muhammadyamin.fkip@gmail.com

\begin{abstract}
Pelatihan masyarakat menjadi tumpuan harapan untuk peningkatan kualitas sumber daya manusia (SDM). Namun demikian, sistim pendidikan kita masih miss match terhadap tuntutan dunia kerja secara nasional maupun regional. Kegiatan ini merupakan upaya memberikan keterampilan mengenai teknis bertenak kambing. Tujuannya untuk meningkatkan pendapatan masyarakat dan menciptakan lapangan kerja khusunya di Desa Gunungsari Kombok Barat. Kegiatan ini melibatkan lima orang dosen 4 orang dari FKIP Unram dan satu orang dari Unismu Mataram serta 17 orang masyarakat dari desa lokasi. Metode yang digunakan dalam kegiatan ini adalah metode Andragogi yaitu menekankan partisipasi aktif dari masyarakat peserta melalui kerja kelompok, demontrasi lapangan, dan diskusi. Kegiatan ini dilaksanakan dengan pemberian teori $15 \%$ dan praktek 85 $\%$. Hasilnya menambah pengalaman, pengetahuan, pemahaman, dan kemauan peserta Pelatihan dalam beternak kambing. Banyak masyarakat dari desa lokasi maupun desa sekitar, bahkan kecamatan lain yang belum mendapat kesempatan meminta kepada Tim Pelaksana agar diikutkan pada Pelatihan keterampilan teknis berikutnya. Selain itu, pelatihan ini benar-benar dirasakan manfaatnya oleh masyarakat khususnya orang tua dan wali santri/siswa yang berekonomi lemah yang tinggal di sekitar Pondok untuk memperoleh sumber penghasilan baru.
\end{abstract}

Keywords: Kambing, teknis, ternak.

menunjukkan prestasinya (Suyanto, 2001). Kenyataan ini merata di seluruh propinsi, termasuk Propinsi Nusa Tenggara Barat.

Seiring dengan otonomi daerah, Pemerintah Daerah (Pemda NTB) bertanggung jawab dalam mengambil keputusan, menyusun, dan melaksanakan program pembangunan pendidikan di daerahnya sesuai dengan kepentingan dan tuntutan masyarakatnya (Bafadal, 2001). Propinsi Nusa Tenggara Barat memiliki kekayaan alam yang cukup besar, namun belum dikelola secara optimal karena terbatasnya jumlah SDM yang 
memiliki pengetahuan dan ketrampilan yang memadai untuk pengelolaanya.

Berdasarkan data statistik tahun 2008, Kecamatan Gunungsari memiliki luas wilayah $79,75 \mathrm{Km}^{2}$. Sekitar $20 \%$ dari luas lahan secara keseluruhan peruntukannya merupakan sawah sistem irigasi teknis dengan musim tanam 3 kali/tahun masing-masing padi 2 kali dan kacangkacangan satu kali. Selain itu, sebagian masyarakat memanfaatkan aliran irigasi teknis yang ada untuk kegiatan budidaya ikan air tawar seperti lele, karper, mujair dan nila. Sedangkan di lahan tegalan, kebun, dan pekarangan, yang luasnya sekitar $80 \%$ dari luas luas keseluruhan wilayah Kecamatan Gunungsari dimanfaatkan untuk tanaman kelapa, kopi, kapuk, kemiri, jambu mete, dan buah-buahan (rambutan, mangga, durian, manggis, nanas, jambu air, jambu biji, dan pisang). Selain bertani, lahan itu (tegalan, kebun, dan pekarangan) dimanfaatkan untuk tempat pemeliharaan ternak seperti (kuda, sapi, kerbau, kambing, babi, dan unggas).

Mata pencaharian penduduk sebagian besar sebagai petani, buruh, pedagang, sopir, tukang ojek, pembantu rumah tangga, pengrajin bambu, Pegewai Negeri orang dan masih mengangur 465 orang (Data Pengelolaan Potensi Desa Gunungsari, 2003). Sebagai daerah pertanian usaha sampingan masyarakat yang potensial dikembangkan untuk meningkatkan pendapatannya adalah beternak kambing. Usaha ini sudah dimulai masyarakat, akan tetapi sistemnya masih konvensional. Untuk ternak (kambing) kandang pemeliharaannya bergabung dengan rumah tinggal. Cara ini berpotensi besar memberikan dampak terhadap penurunan kualitas lingkungan. Berdasarkan studi pendahuluan pada masyarakat di Desa Gunungsari diketahui bahwa sesungguhnya masyarakat setempat mendambakan suatu model pendidikan alternatif yang memungkinkan mereka dapat diberdayakan dalam suatu usaha mandiri.

Dari uraian di atas, dalam usaha meningkatkan pendapatan masyarakat dan menciptakan lapangan kerja "pelatihan ketrampilan teknis bertenak kambing pada kelompok Usaha Mandiri (KWM)" di Desa Gunungsari akan merupakan solusi yang tepat. Apalagi sekarang jumlah penduduk yang kembali dari Malaysia cukup banyak. Kalau tidak ada usaha penanganan secara cepat dan tepat terutama dalam penyediaan lapangan kerja dikhawatirkan akan memicu krisis baru oleh semakin bertambahnya jumlah penganggur.

Oleh karena itu dalam rangka meningkatkan pendapatan dan kesejahteraannya, perlu dilakukan pelatihan ketrampilan teknis beternak kambing sehingga memberikan tambahan pengetahuan dan keterampilan yang sesuai dengan karakter mereka dan potensi sumber daya alam yang tersedia di lingkungannya.

\section{Metode}

Kegiatan ini dilaksanakan selama 10 bulan melibatkan 4 orang pendamping dari dosen Fakultas Keguran dan Ilmu Pendidikan Universitas Mataram, dan satu orang dari Universitas Muhamadiyah Mataram, serta 17 orang masyarakat dari desa lokasi. Status pekerjaan masing-masing peserta pelatihan yaitu 9 (sembilan) orang merupakan orang tua atau wali santri, 1 (satu) orang pemuka masyarakat (Kepala Dusun) dan 7 orang masih berstatus sebagai santri pada tingkat Tsanawiyah dan Aliah. Berdasarkan jenis pekerjaaan peserta sangat bergama yaitu sebagai kusir 4 orang, pengrajin 2 orang,buruh tani, pedagang keliling, dan tukang batu masing-masing 1 orang, dan santri 7 orang. Lebih lengkap dapat dilihat pada lampiran 1 (Daftar hadir Peserta Pelatihan dan Praktik Beternak Kambing di Desa Gunungsari).

Metode yang digunakan dalam kegiatan ini adalah metode Andragogi yaitu menekankan partisipasi aktif dari masyarakat peserta melalui kerja kelompok, demontrasi lapangan, dan diskusi. Kegiatan ini dilaksanakan dengan pemberian teori $15 \%$ dan praktek $85 \%$.

Kegiatan yang telah dilakukan dalam kegiatan ini yaitu:

1. Pendidikan/Pelatihan

Pendidikan/Pelatihan untuk penyampaian materi mengenai petunjuk tehnis tata laksana beternak kambing. Melalui pelatihan ini peserta telah memperoleh pengatahuan riil dari lapangan dan mempraktekan langsung kegiatan usaha yang diperolehnya. Setiap peserta aktif mencari informasi dan terlibat dalam semua kegiatan pelatihan. Pelatihan ini merupakan sarana yang baik untuk belajar dan mendalami halhal yang berguna untuk belajar di lapangan. Karena untuk mengetahui seluk-beluk kegiatan usaha harus diberikan atas dasar belajar mengajar. Untuk itu, sebelum mempraktekan 
konsep tersebut, terlebih dahulu hendaknya mengetahui dan memahami dahulu cara beternak kambing yang baik dan melihat dulu di lapangan, karena suatu konsep dan teori diharapkan selalu beranjak dari lapangan. Teori yang berasal dari lapangan akan dapat dipadukan dengan peengetahuan dan pengalaman yang telah diperoleh sebelumnya.

Adapun materi pendidikan meliputi : (1) mengenal karakteristik ternak kambing, (2) kunci sukses beternak kambing, (3) pemilihan bibit (4) pemberian pakan, (5) kesehatan ternak, dan (6) analisis usaha. Materi tersebut disampaikan dengan ceramah, tanya jawab, dan diskusi.

Respon peserta pada saat penyampaian teori sangat baik, peserta bersemangat, ingin mengetahui berbagai hal mengenai tata laksana beternak kambing yang baik dan benar agar dapat memberikan hasil yang optimal. Demikian pula masyarakat yang belum mendapat kesempatan dalam pelatihan ini silih berganti datang minta didaftar sebagai peserta pelatihan dan pendampingan dalam kegaiatan ini atau kegiatan serupa pada kesempatan berikutnya. Kegiatan pelatihan semacam ini sangat diharapkan oleh hampir seluruh masyarakat di di desa lokasi yang mata pencaharian sebagianbesarny sebagai petani penggarap.

2. Praktik dan Pendampingan Beternak Kambing.

Respon peserta pada saat penyampaian teori dan praktek beternak. Peserta pelatihan sangat senang diikutkan sebagai peserta pelatihan dan praktik beternak kambing. Semua peserta aktif dan semangat mengikuti Pendidikan/Pelatihan yang dilakukan oleh pelaksana selama 3 hari.di desa lokasi. Hal ini ditunjukan dengan kehadiran peserta yang selalu hadir setiap hari mengikuti Pendidikan. Selain itu, program seperti ini telah lama diinginkan sebagian besar masyarakat di desa lokasi, namun karena kendala modal tidak dapat diwujudkan. Seperti telah disebutkan dalam analisis situasi lokasi di atas, sebagian besar masyarakat di desa lokasi berpencaharian sebagai buruh tani dan kusir, sehingga program/kegiatan usaha pendamping yang paling cocok untuk meningkatkan kesejahteraan dan taraf hidupnya adalah beternak kambing.

Dalam hubungannya dengan Program di atas (Pelatihan dan Praktik Beternak Kambing) banyak masyarakat dari desa lokasi maupun desa sekitar, bahkan kecamatan lain yang belum mendapat kesempatan meminta kepada Tim Pelaksana kegiatan ini agar diikutkan pada kesempatan berikutnya.

\section{Hasil dan Pembahasan}

Kegiatan Pendidikan/Pelatihan ini telah menambah pengalaman, pengetahuan, pemahaman, dan kemauan para peserta Pelatihan di desa lokasi (Gunungsari Lombok Barat) dalam beternak kambing. Hal ini terlihat dari aktifitasnya dalam tanya- jawab, dialog, dan diskusi saat mengikuti Pendidikan/Pelatihan. Demikian pula dalam pemeliharaan dan perawatan ternak kambingnya yang rajin, telaten, dan relatif lebih baik dari cara pemeliharaan ternak serupa oleh masyarakat yang lain di desa lokasi dan desa sekitar.

Praktik betrnak kambing oleh para peserta dilakukan secara berkelompok. Kelompok petrnak dari peserta pelatihan ini berjumlah 4 (empat) kelompok, masing-masing terdiri $4-5$ orang. Demikian pula jumlah kambing yang diternakannya oleh masing-masing kelompok berjumlah 4-5 ekor. Ternak kambing yang digunakan dalam kegiatan praktik ini berjumlah 20 (dua puluh) ekor calon induk betina yang berumur antara $8-9$ bulan (siap kawin/dewasa). Dengan demikian diharapkan setelah sekitar 4-5 bulan pemeliharaan ternak kambing tersebut sudah beranak, sehingga peternak cepat memperoleh hasil. Dengan demikian diharapkan dapat membantu meningkatkan pendapatan dan kesejahteraannya. Sehingga kegiatan ini benar-benar dirasakan manfaatnya oleh masyarakat khususnya orang tua dan wali santri/siswa yang berekonomi lemah yang tinggal di sekitar Pondok untuk memperoleh sumber penghasilan baru yaitu dari usaha beternak kambing. Usaha ini selanjutnya diharapkan dapat menambah pendapatannya dan menunjang perekonomian keluarga.santri.

\section{c.1 Mengenal Karakteristik Ternak Kambing}

Kambing merupakan ternak ruminansia makanannya berupa hijauan atau rumputrumputan. Hewan ini dipelihara banyak petani di pedesan sebagai pekerjaan sampingan, namun memiliki andil sangat besar dalam meningkatkan pendapatan dan kesejahteraan keluarga. Hal ini dapat dimaklumi karena 
ternak kambing memiliki beberapa kelbihan yaitu : (1) pemeliharaannya mudah tidak membutuhkan skil dan modal yang besar, (2) dapat dipelihara di lahan kering atau kurang air seperti hampir seluruh wilayah Propinsi Nusa Tenggara Barat, (3) dagingnya diterima dan digemari sebagian besar masyarakat, sehingga mudah dijual bila keadaan ekonomi mendesak, (4) membrikan hasil yang lebih banyak daripada ternak ruminasia lainnya (anak,bulu, dan daging), (5) merupakan sumber protein hewani keluarga, dan (6) kotorannya merupakan pupuk tanaman yang bernilai ekonomi tinggi dan dapat mengemabalikan kesuburan tanah sampai $80 \%$. Apalagi saat ini pupuk an-organik harganya melambung tinggi dan sering menghilang di pasaran.

Dalam beternak kambing, salah satu hal yang penting untuk diperhatikan adalah masalah efisiensi. Yang paling menonjol dalam efisiensi adalah kelahiran rendah, kematian tinggi, pertumbuhan lambat, dan tingginya angka pemotongan induk bunting. Angka kelahiran rendah lebih banyak disebabkan oleh manajemen yang kurang baik, mengenal masa birahi, waktu pengawinan induk yang kurang tepat, dan kondisi induk saat dikawinkan. Selain itu, tipe kambing yang diternakan. Ternak kambing yang dibudi dayakan di Indonesia ada 3 tipe yaitu :

\section{c.1.1 Kambing Tipe Perah}

Kambing tipe ini diternakan untuk diambil susunya. Kambing yang termasuk tipe ini antara lain Kambing Soanen, Kambing Toggenburg, dan Kambing Nubian.

Kambing Soanen berasal dari lembah Soanen di Swiss. Kambing ini dapat menghasilkan susu 3 - 4 liter setiap hari. Ciri-cirinya yaitu : umumnya berwarna putih atau krem, tidak memiliki tanduk baik jantan maupun betina. Dahinya lebar, telinga sedang dantegak, kakinya lurus.

Kambing Toggenburg berasal dari lembah Toggenburg di Swiss Kambing ini dapat menghasilkan susu $3-4$ liter setiap hari. Ciricirinya yaitu : berwarna coklat, pada bagian bawah kaki, bagian samping, dan bawah pangkal leher umumnya terdapat warna putih, tidak bertanduk, telinga besar dan tegak.

\section{c.1.2 Kambing Tipe Pedaging}

Kambing untuk tipe pedaging yang banyak dipelihara orang ada 6 jenis yaitu : kambing
Jawarandu, kambing Kacangan,kambing Ettawa, kambing Kosta, kambing Anggora, kambing Khasmir. Kambing jenis lain adalah kambing tipe dwiguna. Kambing tipe ini diternak untuk diambil susu dan dagingnya. Yang termasuk kambing tipe ini ialah kambing Etawa.

\section{c.2 Kunci Sukses Beternak Kambing}

Dalam usaha budidaya ternak kambing, ada 3 (tiga) hal yang sangat penting diperhatikan untuk mencapai kesuksesan yaitu : (1) bibit, (2) pakan, dan (3) manajemen usaha.

\section{c.2.1 Pemilihan Bibit Kambing yang Diternak}

Pemilihan bibit sebagai calon induk betina maupun pejantan dari ternak kambing dimaksudkan untuk memperoleh keturunan yang memiliki sifat-sifat yang baik seperti kesuburan, prosentase kelahiran yang tinggi, kecepatan tumbuh yang baik, dan produksi susu yang cukup sehingga pemeliharaannya efisien dan menguntungkan. Untuk maksud tersebut, perlu diperhatihan hal berikut seperti: kesehatan calon induk baik jantan maupun betina, ukuran tubuh, temperamen, kemampuan menghasilkan susu, bobot lahir dan bobot sapih, kemampuan merumput, selsilah, kondisi lingkungan tempat beternak akan dilakukan, jJenis yang disukai masyarakat, harga pasar dan permintaan hasil utama dan biaya dan ketersediaan bibit.

\section{c.2.2 Pemberian Pakan}

Makanan yang diberikan pada ternak kambing ada 2 macam yaitu makanan hijauan/rumput-rumputan dan makanan penguat yang terdiri dari dedak halus, jagung bungkil kacang, onggok, dan ampas tahu. pemberian pakan ini biasanya $2-3 \mathrm{kali} / \mathrm{hari}$ dengan jadwal pagi makanan penguat, siang dan sore hari hijauan. Pemberian pakan meskipun kita sudah tahu jumlahnya tetapi hendaknya diberikan sedikit-sedikit tidak sekaligus agar ternak tidak memilih-milih atau banyak makanan yang terbuang. Untuk kambing yang digembalakan hendaknya dilepas setelah agak siang agar air embun dan telur-telur parasit cacing sudah tidak lagi muncul di daun rumput ksrena sudah panas. Sedangkan untuk air minum diberikan yang bersih yang tidak mengandung zat-zat lain. Pemberiannya diperhitungkan 1-2 liter/ekor kambing dewasa tergantung pada jenis 
ternak, makanan, dan cuaca.

Pakan kambing betina dewasa berupa hijauan dan konsentrat. Sebanyak sekkiatar $10 \%$ berat badan. Selain itu perlu diberi pakan penguat se banyak $1 \%$ dari berat badan. Sedangkan untuk pejantan dewasa pakannya berupa rumput dan leguminosa sebanyak 6- $8 \mathrm{~kg} / \mathrm{ekor} / \mathrm{hari}$ dan pakan penguat $0,4-0,5 \mathrm{~kg} /$ ekor/hari. Salah satu contoh penysunan makanan penguat untuk ternak kambing seperti berikut: dedak halus $70,9 \%$; jagung kuning halus $18,9 \%$; bungkil kacang tanah $1,8 \%$; bungkil kelapa $5,0 \%$; tepung tulang $2,4 \%$; garam dapur 1,0 $\%$.

\section{c.2.3 Manajemen Usaha}

Kesuksesan dalam berusaha termasuk beternak kambing sangat ditentukanoleh manajemen usaha. Manajemen usaha beternak kambing meliputi 3 (tiga) kegiatan yaitu : a) Budi daya, b) Pemasaran dan c) Sumber Daya Manusia

\section{c.3 Perkembangbiakan dan Tata Laksana Beternak Kambing}

\section{c.3.1 Pengebangbiakan Ternak Kambing}

Dalam beternak kambing salah satu hal yang sangat penting diketahui dan dipahami oleh peternak adalah bagaimana cara pengembangbikannya yang baik. Dengan pengembangbiakan yang baik akan diperoleh hasil yang seoptimal mungkin. Pengembangbiakan adalah kegiatan yang bertujuan agar kambing yang diternakan menghasilkan anak sehingga jumlahnya bertambah banyak dan kualitasnya meningkat. Proses ini perlu diketahui dan dipahami benar oleh peternak dengan baik. Berkaitan dengan hal ini beberpa hal yang perlu diketahui dan pahami benar oleh peternak antara lain yaitu :

1. Umur puber. Umur Baliq/Puber. Kambing mencapai umur baliq/puber umumnya sejak berumur $7-9$ bulan. Anak betina lebih lama mencapai umur puber dibandingkan dengan pejantan. Pada tipe pedaging kambing betina mencapai baliq umumnya pada umur $8-10$ bulan, pada jenis kambing yang tubuhnya berukuran besar mencapai baliq lebih dari 10 bulan yaitu 16 -20 bulan. Tanda-tanda birahi biasanya ditunjukan dengan kelihatan gelisah, ribut/mengembek-ngembek, nafsu makan berkurang, diambila dinaiki pejantan, ekor sering dikibas-kibas, sering kencing, vulva membesar (bengkak) warna merah jambu, dan kadang-kadang keluar lendir. Dari sekian banyak tanda-tanda puber, pada umumnya hanya sebagian kecil yang dapat diamati. Oleh karena itu, maka peternak harus teliti dalam pengamatan tanda-tanda birahi agar tidak kehilangan kesempatan dalam melaksanakan program peengembangbiakan yang efesien. Masa birahi yang dialami seekor ternak erat kaitannya dengan siklus birahi, ovulasi, dan lamabirahi.

2. Periode birahi Siklus birahi. Kambing termasuk polyesterus artinya bahwa kambing betina yang sudah masak seksual pada setiap periode tertentu akan timbul birahi secara rutin. Periode birahi kambing betina akan selalu berulang antara 15-20 hari atau rata-rata setiap 17 hari sekali.

3. Umur Perkawinan. Semua ternak,termasuk kambing perlu perkawinan yang terarah, karena hal ini merupakan salah satu bentuk perwujudan perkembangbiakan yang produktif. Oleh karena itu, semua proses harus diperhatikan. Beberapa hal yang perlu diperhatikan dalam perkawinan ternak kambing yaitu: persiapan perkawinan, kunci keberhasilan perkawinan, perkawinan pertama, perkawinan yang tepat, pengaturan perkawinan, tata laksana perkawinan, perkawinan sebangsa dan perkawinan silang, dan memperkirakan umur dengan susunan gigi.

4. Persiapan Perkawinan. Untuk perkwianan ternak kambing ada beberapa persiapan yang perlu dilakukan antara lain yaitu : (1) Pemeriksaan induk yang pernah beranak. Induk kambing yang pernah beranak setelah sekitar 2 bulan sudah dapat dikawinkan kembali.. (2) Pemberian pakan yang bermutu. Induk yang akan dikawinkan perlu diberi pakan yang bermutu. Pakannya selain hijauan perlu diberi konsentrat sebanyak 0,5 kg/hari/ekor selama3 minggu. (3) Pemotongan bulu. Bulu di sekitar alat reproduksi dibersihkan/dicukur. 


\section{Kunci keberhasilan Perkawinan.} Keberhasilan perkawinan ternak kambing tergantung dari kesuburan betina dan pejantan serta pengaturan perkawinannya oleh peternak. Oleh karena itu peternak harus memperhatikan tingkah laku ternak pelihraannya. Agar peternak dapat melakukan perkawinan ternaknya dengan baik harus mengetahui hal berikuit :

a. Umur kambing mulai masak seksual. Kambing mencapai umur baliq/puber umumnya sejak berumur $7-9$ bulan. Anak betina lebih lama mencapai umur baliq dibandingkan dengan pejantan. Pada tipe pedaging kambing betina mencapai baliq umumnya pada umur 8 10 bulan.

Umur kambing mulai dikawinkan. Seperti disebutkan di atas, ternak kambing sudah masakseksual mulai umur 8 bulan. Pada umur ini ternak sudah bisa dikawinkan, namun lebih baik bila sudah berumur lebih dari satu tahun.

b. Siklus birahi. Periode Birahi. Kambing betina hanya mau menerima pejantan untuk dikawini pada periode tertentu saja, yakni pada masa birahi. Di luar masa itu kambing betina tidak mau dekat dan tidak mau didekati pejantan. Lama birahi. Lama birahi pada ternak kambing berkisar antara $20-42$ jam. Pada periode inilah (hari kedua birahi) pengawinan ternak kambing yang tepat dilakukan.

c. Ovulasi. Ovulasi pada ternak kambing terjadi 24 - 30 jam atau $1-2$ hari sesudah birahi berlangsung. Setiap periode ovulasi umumnya melepaskan 1-2 butir sel telur yang matang. Jumlah sel telur yang dihasilkan sangat dipengaruhi oleh kualitas pakan yang disajikan,umur, dan berat badan ternak. Semakin bertambah umur, berat badan induk dan kualitas pakan, maka jumklah sel telur yang dihasilkan semakin meningkat

d. Waktu mengawinkan. Pada tipe pedaging kambing betina mencapai baliq umumnya pada umur $8-10$ bulan, pada jenis kambing yang tubuhnya berukuran besar mencapai baliq lebih dari 10 bulan yaitu $16-20$ bulan.. Tanda-tanda birahi biasanya ditunjukan dengan kelihatan gelisah, ribut/mengembek-ngembek, nafsu makan berkurang, diam bila dinaiki pejantan, ekor sering dikibas-kibas, sering kencing, vulva membesar (bengkak) warna merah jambu, dan kadang-kadang keluar lendir. Dari sekian banyak tanda-tanda puber, pada umumnya hanya sebagian kecil yang dapat diamati. Oleh karena itu, maka peternak harus teliti dalam pengamatan tanda-tanda birahi agar tidak kehilangan kesempatan dalam melaksanakan program peengembangbiakan yang efesien. Masa birahi yang dialami seekor ternak erat kaitannya dengan siklus birahi, ovulasi, dan lamabirahi.

e. Kebuntingan. Kebuntingan adalah jangka waktu perkembangan janin di dalam uterus (rahim) smapai beranak. Lama kebuntingan pada ternak kambing beragam yaitu berkisar antara $144-152$ hari atau rata-rata 148 hari (sekitar 5 bulan). Sesudah terjadi kebuntingan pada ternak kambing, maka siklus birahi yang biasanya terjadi setiap 17 hari sekali akan terhenti.

Tanda-tanda awal terjadi kebuntingan pada ternak kambing sulit diketahui secara visual, namun dapat diperkirakan dari perubahan prilaku beriku: birahi berikutnya tidak muncul/terlihat lagi, prilakunya tenang tidak ingin didekati dan mendekati pejantan, nafsu makan meningkat, bobot badan bertambah, dan semakin gemuk, Pada pertengahan kebuntingan perut sebelah kanan membesar dan menonjol, waktu penyapihan, batas umur produktif diternakan dan permabndingan antara pejantan dengan betina.

f. Kelahiran anak. Beberapa hal yang perlu diketahui dan dipahami oleh peternak sehubungan dengan kelahiran anak kambing antara lain yaitu : persiapan kelahiran, tanda-tanda kelahiran ternak kambing sudah dekat dan proses 
kelahiran anak ternak.

\section{c.4 Tata Laksana Beternak Kambing}

Untuk mendapatkan hasil yang optimal dari usaha beternak kambing, campur tangan peternak memegang peranan sangat penting dalam duah hal yaitu pemeliharaan dan perwatan ternak.

\section{c.4.1 Perawatan}

Perawatan merupakan salah satu bagian dari pemeliharaan yang tidak dapat diabaikan. Upaya perawatan ternak kambing yang harus dilakukan secara rutin ada 4 (empat) hal yaitu :

1. Memandikan. Pemandian Ternak : Kambing perlu dimandikan agar tidak kotor dan menjadi sarang kuman penyakit. Pemandian sebaiknya dilakukan secara rutin pada waktu cuaca cerah satu kali seminggu. Air yang digunakan sebaiknya air yang bersih dan mengalir.

2. Mencukur bulu. Pencukuran Bulu. Bulu kambing yang panjang dan tidak pernah dirawat akan menjadi kotor dan gembel sehingga dapat menjadi tempat sarang penyakit dan parasit. Pencukuran dilakukan cukup satu kali setahun. Panjang bulu yang disisakan sekitar 0,5-1 cm.

3. Memotong kuku. Pemotongan Kuku : Kuku-kuku ternak kambing yang sudah panjang perlu dipotong secara rutin, karena akan menggangu aktivitas dan kesehatannya. Kuku yang panjang akan menjadi kotor dan tempat sarang kuman penyakit.

4. Kastrasi (pengebirian). Pengebirian : Pengebirian dilakukan pada ternak kambing yang tidak akan dijadikan bibit, tujuannya tujuan antara lain agar ternak tidak liar (jinak), sehingga memudakan pemeliaharaan, untuk menghindari kabing jantan kualitas jelek mengawini induk kambing betina kualitas bagus, dan mempercepat penimbunan serta meningkatkan kualitas daging ternak. Pengebirian ternak kambing sebaiknya dilakukan pada saat berumur 1-2 minggu. Pengebirian dapat dilakukan dengan cara : (1) cara operasi terbuka yaitu memotong seper tiga ujung skrotum dengan pisau, (2) mengikat skrotum dengan karet elastrator sehingga skrotum dan testes mengering dan akhirnya lepas/putus dengan sendirinya, (3) kastrasi dengan tang burdizzo yaitu menjepit saluran testes sehingga terputus dan sekain lama semakin mengering. Cara ini dilakukan pada anak kambing berumur 4-6 minggu, dan (4) kastrasi dengan alat emasculator.

\section{c.4.2 Pemeliharaan :}

Pemeliharaan ternak kambing dilakukan pada seluruh fase hidupnya, yaitu sejak dilahirkan sampai dengan dewasa.

Pemeliharaan Kambing Dewasa. Pemeliharaan kambing dewasa dapat dikelompokan menjadi dua kelompok yaitu kelompok kambing betina dewasa dan kambing pejantan dewasa.

Pemeliharaan kambing betina dewasa (induk betina). Induk kambing khususnya induk betina membutuhkan perawatan yang baik, terutama ketika sedang bunting. Oleh karena itu, peternak perlu memperhatikan hal berikut :

1. Pakan. Pakan harus diperhatikan jumlah dan kualitasnya. Pakan kambing betina dewasa berupa hijauan dan konsentrat. Jumlah pemberian pakan setiap hari sebanyak sekkiatar $10 \%$ dari berat badan. Selain itu perlu diberi pakan penguat se banyak $1 \%$ dari berat badan.

2. Kandang. Induk kambing yang sedang bunting kandangnya dipisahkan. Ukurannya sekitar $1 \mathrm{~m}$ x 1,5 m. Lantai diberi jerami yang kering. dengan yang lain: Pergerakan. Induk kambing yang akan beranak harus dilatih bergerak, atau jalan-jalan menuju kandang agar mudah saat beranak. Penyapihan. Penyapihan anak kambing secara alami berlangsung setelah berumur 4-5 bulan. Untuk mejaga kesehatan induk dan meningkatkan produksi penyapihan dapat dipersingkat/dipercepat menjadi 2-3 bulan bila kondisi anak cukup baik.. Reproduksi induk betina dewasa dapat diprogramkan : terus menerus, delapan bulan sekali, atau 


\section{7,5- 8 bulan sekali.}

Pemeliharaan Induk Kambing Pejantan. Seperti halnya induk betina, induk jantan pun mebutuhkan perawatan yang baik. Pejantan dewasa pakannya berupa rumput dan leguminosa sebanyak 6- $8 \mathrm{~kg} / \mathrm{ekor} / \mathrm{hari}$ danpakan penguat 0,4 $-0,5 \mathrm{~kg} / \mathrm{ekor} / \mathrm{hari}$. Penggunaan pejantan ditentukan pada umur. Semakin dewasa semakin bnayak /sering dapat melayani betinauntukdikawinkan. Pejantan mulai dari umur 8 bulan dapat melayani betina $1 \mathrm{kali} / \mathrm{minggu}$, sedang pejantan 20 bulan dapat melayani betina $4 \mathrm{kali} /$ minggu. Satu ekor pejantan dapat melayani $25-30$ ekor betina tergantungpada umur pejantan dan sistemperkawinan. Umur pejantan yang baik adalah sekitar 1,5 tahun. Ciri-ciri pejantan yang dianggap baik oleh peternak yaitu : agresif, kepala besar, leher berbobot dankuat, badan bagian muka padat, mulut lebar, hidung besar, mata luas, penglihatanberani, telinga hidup, susu besar, suara nyaring dan dalam.

\section{C.5 Kesehatan Ternak Kambing Penyakit Ternak Kambing dan Pengobatannya}

Sanitasi peternakan kambing perlu mendapat perhatian khusus, karena sanitasi kurang baik mengundang berbagai penyakit dan kuman yang akan mengakibatkangagalnya produksi. Dengan sanitasi yang baik diharapkan akan mencegah timbulnya penyakit dan parasit. Pencegahan penyakit merupakan tindakan yang lebih menguntungkan daripada pengobatan,karena ternak yang pernah sakit harganyalebih murah dibandingkan dengan ternak yang tidak pernah terkena penyakit. Selain itu pencegahan lebih murah dari biaya pengobatannya.

Kebersihan kandang merupakan salah satu usaha pencegahan penyakit dan parasit. Kandang ternak kambing hendaknya tidak lembab dan basah, ventilasinya cukup. Penyakit kambing sering diakibatkan oleh peternak dalam menempatkan kambing di dalam kandang. Kesalahan yang sering terjadi adalah : kandang kotor, lemba, dan basah, sirkulasi udara tidak lancar, makanan kurang baik.

Penyakit-penyakit yang sering menyerang ternak kambing yaitu: Erythym cstogiosa (radang kulit sekitar bibir). Penyebabnya virus. Menyerang ternak kambing pada setiap tingkat umur. Penyakit ini belum pernah menyababkan; kematian, namun pemberian disinfektan dapat mempercepat penyembuhan ternak; Scabies atau kurap/kudis.
Penyakit ini disebabkan oleh parasit tungau. Pengobatannya: Serbuk belerang, parutan kunyit, minyak kelapa masing-masing satu bagian kemudian dicampur dan dipanaskan. Selanjutnya dioleskan pada bagian ternak yang sakit. Cacingan. Penyakit ini disebabkanoleh cacing seperti Ascaridia sp. Obatnya adalah 5-10 gram bjij kacang tanah, tepung pinang segennggam. Bahan tersebut dicampur merata kemudian diminumkan pada ternak kambing yang sakit. Obat lain dapat dibeli di Toko obat hewan seperti Piperazine puder. Pneumonia. Penyebabnya kandang ternak lembab, dingin dan kotor. Penyakit ini umunya menyerang ternak yang muda. Pengobatannnya ternak harus sering dikenakan matahari pagi, dan kandang dikeringkan. Bloat. Penyebabnya adalah karena kambing merumput saat masih basah atau hujan. Pengobatannya ternak kambing ditempatkan di tempat yang miring bagian kepala/depan menghadap ke tempat yang lebih tinggi. Kontipas, yaitu kotoran keras tidak mau keluar, umumnya menyerang ternak yang masih muda (anak). Pengobatannya air sabun dimasukan ke dalam dubur ternak dengan selang. Anthrax. Penyakit ini dapat menyerang ternak dan manusia. Peenyebabnya adalah basil Anthrax. Hewan ternak yang mendapat penyakit tersebut harus mendapat perhatian khusus. Semua hewan mati yang terkena penyakit tersebut harus dibakar atau dikuburkan. Tetanus. Penyakit ini disebabkan oleh basil Tetanus. Ternak menderita penyakit ini biasanay setelah hewan ternak mengalami luka misalnya karena kastrasi, pencukuran, penandaan dengan pemotongan bagian tubuh dan lainnya. Pengobatannya tidak mempunyai arti. Pencegahannya adalah dengan penggunaaan alatalat yang steril.

\section{Kesimpulan}

Dari uraian dan pembahasan di atas mengenai pemberdayaan masyarakat khususnya di Desa Gunungsari Kabupaten Lombok Barat, dapat disimpulkan bahwa upaya meningkatkan pendapatan masyarakat dan menciptakan lapangan kerja "pelatihan ketrampilan teknis" merupakan solusi yang tepat untuk memberikan tambahan pengetahuan dan keterampilan yang sesuai dengan karakter masyarakat dan potensi sumber daya alam yang tersedia di lingkungannya 


\section{Ucapan Terima Kasih}

Kami menyampaikanTerima Kasih Kepada Badan Perencanaan Pembangunan Daerah Propinsi Nusa Tenggara Barat yang telah memberikan dana Pemberdayaan Masyarakat ini dan Kepala Desa Gunungsari Kabupaten Lombok Barat yang telah membantu di Lapangan.

\section{Daftar Pustaka}

Direktorat Pendidikan Keagamaan dan pondok Pesantren, Direktorat Jendral Kelembagaan Agama Islam DEPAG, Materi Pelatihan Agribisnis bagi Pondok Pesantren, Cisarua Bogor.

Mulyono dan Subangkit, 1998. Teknik Pembibitan Kambing dan Domba, Penebar Swadaya, Jakarta.

Reksohadiputro, S., 1985. Pengembangan Peternakan di Daerah Transmigrasi, BPFE, Yogyakarta.

Rismunandar dan Budihartini, 1985. Mengenal Serangga Parasit pada Kambing dan Domba, Sinar Baru, Bandung.

Sudamono, A. S., Y. Bambang Sugeng, 2003.

Beternak Domba, Seri Agribisnis, Edisi

Revisi, Penebar Swadaya, Jakarta.

Sumoprastowo, C.D.A., 1980. Betrnak Kambing Yang Berhasil, Bahtera Kaarya Sukses,Jakarta.

Wahyu Muljana, 2001. Cara Beternak Kambing, Aneka Ilmu, Semarang. 